\title{
Impact of nucleation on global CCN
}

\author{
J. Merikanto, D. V. Spracklen, G. W. Mann, S. J. Pickering, and K. S. Carslaw \\ School of Earth and Environment, University of Leeds, Leeds, UK \\ Received: 27 April 2009 - Published in Atmos. Chem. Phys. Discuss.: 9 June 2009 \\ Revised: 31 October 2009 - Accepted: 3 November 2009 - Published: 12 November 2009
}

\begin{abstract}
Cloud condensation nuclei $(\mathrm{CCN})$ are derived from particles emitted directly into the atmosphere (primary emissions) or from the growth of nanometer-sized particles nucleated in the atmosphere. It is important to separate these two sources because they respond in different ways to gas and particle emission control strategies and environmental changes. Here, we use a global aerosol microphysics model to quantify the contribution of primary and nucleated particles to global CCN. The model considers primary emissions of sea spray, sulfate and carbonaceous particles, and nucleation processes appropriate for the free troposphere and boundary layer. We estimate that $45 \%$ of global low-level cloud $\mathrm{CCN}$ at $0.2 \%$ supersaturation are secondary aerosol derived from nucleation (ranging between $31-49 \%$ taking into account uncertainties in primary emissions and nucleation rates), with the remainder from primary emissions. The model suggests that $35 \%$ of $\mathrm{CCN}(0.2 \%)$ in global low-level clouds were created in the free and upper troposphere. In the marine boundary layer $55 \%$ of $\mathrm{CCN}(0.2 \%)$ are from nucleation, with $45 \%$ entrained from the free troposphere and $10 \%$ nucleated directly in the boundary layer. Combinations of model runs show that primary and nucleated $\mathrm{CCN}$ are non-linearly coupled. In particular, boundary layer nucleated CCN are strongly suppressed by both primary emissions and entrainment of particles nucleated in the free troposphere. Elimination of all primary emissions reduces global CCN $(0.2 \%)$ by only $20 \%$ and elimination of upper tropospheric nucleation reduces CCN $(0.2 \%)$ by only $12 \%$ because of the increased contribution from boundary layer nucleation.
\end{abstract}

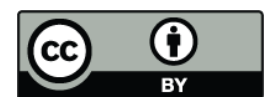

Correspondence to: J. Merikanto (j.merikanto@leeds.ac.uk)

\section{Introduction}

Atmospheric particles are produced by two distinctly different mechanisms: Particulate emissions produce primary particles spanning a wide range of sizes, and gas-to-particle conversion creates nanometer-sized particles by atmospheric nucleation. These production mechanisms differ greatly in their spatial and temporal variations and the factors that control these variations. For example, particulate emissions occur almost universally close to the ground whereas nucleation occurs in the boundary layer (Kulmala et al., 2004) and in the upper troposphere (Twohy et al., 2002; Benson et al., 2008). While the atmospheric abundance of primary particles is essentially determined by the emission strength, the abundance of nucleated particles responds in complex ways to variations in precursor gases and existing particle concentrations (Gaydos et al., 2005; Spracklen et al., 2006; Jung et al., 2006; Pierce and Adams, 2007; Wang and Penner, 2009) and other environmental factors that are still not completely understood (Lyubovtseva et al., 2005; Sogacheva et al., 2008).

Quantification of the global budget of $\mathrm{CCN}$ is an essential step towards a complete understanding of how anthropogenic emissions alter global clouds and climate. Prediction of long-term changes in $\mathrm{CCN}$ for climate assessments needs to account for the variations and couplings in different aerosol production mechanisms. To do so requires an understanding of the budget of primary and nucleated $\mathrm{CCN}$ in different regions and the factors that control changes in their abundance. At present, the relative strength of different mechanisms contributing to the budget of total aerosol (condensation nucleus, $\mathrm{CN}$ ) and $\mathrm{CCN}$ concentrations is not known.

Our limited understanding of the global $\mathrm{CCN}$ budget is partly due to the limited capability of global models to represent detailed particle microphysics. Only recently global models that can simulate changes in particle number concentration and the particle size distribution with

Published by Copernicus Publications on behalf of the European Geosciences Union. 
particle microphysics have become available (Adams and Seinfeld, 2002; Vignati et al., 2004; Spracklen et al., 2005a; Lohmann et al., 2007; Wang et al., 2009). However, there are also uncertainties in emissions, particularly for carbonaceous particles (Bond et al., 2004), but also for precursor gases such as sulfur dioxide (Smith et al., 2002) and the fraction of the sulfur emitted as particulate sulfate from nearinstantaneous sub-grid scale nucleation close to the emission source (Spracklen et al., 2005b; Wang and Penner, 2009). Also, one of the largest current challenges is to understand in more detail how secondary organic compounds contribute to aerosol growth (Alfarra, 2006) and possibly to their formation (Bonn et al., 2008; Laaksonen et al., 2008).

Recently, substantial advances have been made in our understanding of what controls atmospheric nucleation (Kulmala et al., 2006, 2008). While work is in progress to better quantify different aerosol processes, global models including detailed microphysics have contributed greatly to the knowledge of mechanisms controlling particle concentrations in different regions. Pierce and Adams (2006), Kazil et al. (2006) and Spracklen et al. (2007) showed that remote marine boundary layer $\mathrm{CCN}$ concentrations can be largely explained by the primary sea salt flux and entrainment of free tropospheric particles, as originally proposed by Raes (1995). In a subsequent study Korhonen et al. (2008) used a global aerosol model to explain the seasonal cycle of CCN at Cape Grim based on emissions of sea spray and nucleation of sulfuric acid aerosol in the free troposphere, and estimated that over $90 \%$ of the non-sea spray CCN were generated above the boundary layer by nucleation.

Several studies have shown that changes in emissions can result in non-linear changes in aerosol number concentrations. Stier et al. (2006) studied the non-linear responses of aerosol concentrations to all major aerosol sources, and found that the new particle production by binary homogeneous sulfuric acid-water nucleation was saturated so that a decrease in sulfuric acid concentration produced less than a proportional decrease in nucleation and accumulation mode particles. On the other hand, changes in primary organic emissions showed more than proportional changes in accumulation mode particles. Pierce et al. (2007) found that the total enhancement of surface level CCN $(0.2 \%)$ from all carbonaceous particles is $65-90 \%$ depending on the applied emission inventory. Spracklen et al. (2006) showed that reduction in primary emissions can actually increase ground level $\mathrm{CN}$ due to enhanced nucleation in the boundary layer. Similarly, Wang and Penner (2009) showed that the enhancement of CCN production by boundary layer nucleation is greater when a smaller proportion of sulfur emissions is emitted directly as primary sulfate.

The uncertainties in nucleation parameterizations have also been studied in several global models. Pierce and Adams (2009) found that boundary layer CCN $(0.2 \%)$ concentrations obtained with different atmospheric nucleation parameterizations varied only by $12 \%$, and concluded that uncertain- ties in primary emissions are more important for $\mathrm{CCN}$ concentrations than uncertainties in nucleation rates. Spracklen et al. (2008) showed that uncertainties in boundary layer nucleation rates alone lead to enhancements between 3-20\% in ground level global CCN $(0.2 \%)$. Also, Makkonen et al. (2009) showed that boundary layer cloud droplet number concentrations (CDNC) are highly sensitive to the selected boundary layer nucleation parameterization.

Recently, we used a global aerosol microphysics model GLOMAP to fine-tune the model boundary layer nucleation parameterization against observed $\mathrm{CN}$ concentrations (Spracklen et al., 2006, 2009), CCN concentrations (Spracklen et al., 2008), and CDNC (Merikanto et al., 2009). Our comparisons of modeled and observed $\mathrm{CN}, \mathrm{CCN}$ and CDNC show that the model gives a satisfactory representation of the boundary layer aerosol. Here, our aim is to provide a best possible estimate of the relative contribution to global and regional $\mathrm{CN}$ and $\mathrm{CCN}$ of primary particles and secondary particles both from boundary layer and free tropospheric nucleation. Changes in these contributions due to uncertainties in primary particle emissions and nucleation rates are also taken into account. The simulations are based on inventories for year 2000 particulate and precursor gas emissions.

\section{Model description}

GLOMAP is an extension of the offline 3-D chemical transport model TOMCAT (Chipperfield, 2006). GLOMAP treats two 2-moment sectional externally mixed particle distributions. One distribution is partly hydrophyllic including sulfate, sea-salt, elemental carbon (EC) and organic carbon $(\mathrm{OC})$, and the other is hydrophobic containing freshly emitted primary carbon (OC and EC). In this study we have neglected dust as an aerosol component in favour of computational efficiency. While dust can be an important source of ice nuclei and makes a significant proportion of aerosol mass in some regions, the number concentration of dust is always low compared to other aerosol types. Our resent modelling results including dust have shown that dust makes only a minor contribution to $\mathrm{CN}$ or $\mathrm{CCN}$ even during severe dust storms (Manktelow et al., 2009). Therefore, neglecting dust has no significant impact on our results.

Primary OC and EC particles are transferred to the hydrophyllic distribution through coagulation with other hydrophyllic particles or by condensation of one monolayer of sulfuric acid or secondary organics, making the transfer of OC and EC to the hydrophyllic distribution fairly rapid. Rapid aging of hydrophyllic primary particles is also observed in laboratory measurements (Zhang et al., 2008). Here we use a horizontal resolution of $\sim 2.8^{\circ}$ by $\sim 2.8^{\circ}$ with 31 vertical levels between the surface and $10 \mathrm{hPa}$. The model is forced by analyses from the European Centre for MediumRange Weather Forecasts for the year 2000. Microphysical 
Table 1. Description of modelled source strengths for different particle production mechanisms. The primary emitted particles mass fluxes are taken from AEROCOM emissions datasets (Dentener et al., 2006). Table shows the applied size distributions schemes. Nucleation schemes refer to applied parameterization or nucleation rate coefficient. Minimum, standard and maximum schemes refer to the relative strength of the sources in producing particles globally.

\begin{tabular}{lllll}
\hline Source & Type & Minimum scheme & Standard scheme & Maximum scheme \\
\hline Primary & EC & Stier et al. (2005) & Stier et al. (2005) & AEROCOM \\
& OC & Stier et al. (2005) & Stier et al. (2005) & AEROCOM \\
& Sulfate & AEROCOM & AEROCOM & AEROCOM \\
& Sea-salt & Gong (2003) & Martensson et al. (2003) & Martensson et al. (2003) \\
UTN & $\mathrm{H}_{2} \mathrm{SO}_{4}-\mathrm{H}_{2} \mathrm{O}$ & Kulmala et al. (1998) & Kulmala et al. (1998) & Vehkamäki et al. (2002) \\
BLN & Activation & $A=2 \times 10^{-7}$ & $A=2 \times 10^{-6}$ & $A=2 \times 10^{-5}$ \\
\hline
\end{tabular}

processes include nucleation, primary particle emissions, condensation, coagulation, in-cloud and below-cloud aerosol wet deposition, dry deposition, and cloud processing. Full details of the model microphysics scheme are described in Spracklen et al. (2005a).

We model the aerosol size distribution with 20 sections spanning $3 \mathrm{~nm}$ to $10 \mu \mathrm{m}$ dry diameter. The lower limit of $3 \mathrm{~nm}$ is also a typical lower limit in commercial Differential Mobility Particle Sizer (DMPS) devices applied in field measurements. The modeled CN concentration is calculated as the sum of all particles of all sizes in both hydrophyllic and hydrophobic distributions. CCN concentrations are calculated from the hydrophyllic distribution using the dry radius and hygroscopicity $\kappa$. The $\kappa$ values are obtained from Petters and Kreidenweis (2007) for different chemical species and the calculations are carried out using fixed supersaturations of $0.2 \%$ and $1.0 \%$.

\subsection{Particulate and gaseous emissions}

Particulate emissions are based on AEROCOM prescribed emission datasets for the year 2000 (Dentener et al., 2006). The datasets include sea-salt and particulate carbonaceous emissions (EC and OC), and sulfate emissions from wildfires, biofuels, fossil fuels and volcanoes. Particulate sulfate originates from nucleation that takes place almost instantly close to emission source, and is therefore treated here as a source of primary particles. Here, we emit $2.5 \%$ of all $\mathrm{SO}_{2}$ emissions as particulate sulfate. Primary sulfate are emitted as lognormal modes according to AEROCOM recommendations that are then mapped to the model size bins. For EC/OC emissions we use the size distribution suggested by Stier et al. (2005). However, uncertainties in primary particle concentrations are studied with additional simulations using AEROCOM-recommended size distribution for EC/OC particles, which increases the number yield of EC/OC particles by a factor of eight compared to Stier et al. (2005) scheme. The sea-salt size distribution is also modeled according to two different schemes. The first scheme is based on the AEROCOM recommendation (Gong, 2003). This scheme does not include ultrafine sea-salt particles that have been found to greatly contribute to marine $\mathrm{CN}$ and $\mathrm{CCN}$ concentrations (Pierce and Adams, 2006; Clarke et al., 2006). Therefore, another scheme by Martensson et al. (2003), which emits seasalt particles down to $10 \mathrm{~nm}$, is also explored. The different particulate emission schemes are summarised in Table 1.

We use AEROCOM-recommended anthropogenic and volcanic emissions of $\mathrm{SO}_{2}$ and marine DMS emissions are obtained from prescribed concentrations by Kettle and Adreae (2000) and sea-to-air transfer velocities according to Nightingale at al. (2000). The model gas phase sulfur chemistry mechanism used for atmospheric sulfuric acid production rates is described in Spracklen et al. (2005a). The organic condensable and hydrophilic secondary organic aerosol material is obtained as first-stage oxidation products of monoterpenes with an assumed yield of $13 \%$. Monoterpene emissions are from the GEIA inventory (Benkovitz et al., 1996). The applied oxidation reactions are explained in Spracklen et al. (2006).

\subsection{Model nucleation schemes}

New particle formation is modeled with two mechanisms based on nucleation of secondary sulfate particles. The first mechanism is binary homogeneous nucleation (BHN) of sulfuric acid and water using rates from the parameterization of Kulmala et al. (1998). Recent theoretical and experimental work suggests that BHN does not produce significant nucleation in the boundary layer (Kulmala et al., 2006; Young et al., 2008). Indeed, in our model BHN does not produce significant nucleation in the boundary layer, but takes place actively above this height. Our earlier work also suggests that BHN is capable of producing the measured particle concentrations in the upper troposphere (Spracklen et al., 2005a). Another BHN parameterization by Vehkamäki et al. (2002) is also applied in the uncertainty analysis and produces somewhat higher nucleation rates in the upper troposphere than Kulmala et al. (1998).

The second nucleation mechanism is based on cluster activation theory by Kulmala et al. (2006). Observations from 
several ground stations around the world suggest that the nucleation rate of new particles is proportional to the sulfuric acid concentration to the power of 1 or 2 (Weber et al., 1995, 1997; Sihto et al., 2006; Riipinen et al., 2007; Kuang et al., 2008). Activation theory gives the nucleation rate of $1 \mathrm{~nm}$ particles by

$J_{1}=A\left[\mathrm{H}_{2} \mathrm{SO}_{4}\right]$,

where $A$ is the nucleation rate coefficient. The effective production rate of $3 \mathrm{~nm}$ particles is obtained from (Kerminen and Kulmala, 2002)

$J_{3}=J_{1} \exp \left(-0.153 \frac{\mathrm{CS}^{\prime}}{\mathrm{GR}}\right)$,

where $\mathrm{CS}^{\prime}$ is the reduced condensation sink and $\mathrm{GR}\left(\mathrm{nm} \mathrm{h}^{-1}\right)$ is the cluster growth rate, assumed to be constant between 1 and $3 \mathrm{~nm}$ and given by $0.73 \times 10^{-7}\left[\mathrm{H}_{2} \mathrm{SO}_{4}\right]$. Modeled $\mathrm{CN}$ and $\mathrm{CCN}$ concentrations are in relatively good agreement with worldwide observations when this scheme is included (Spracklen et al., 2006, 2008, 2009) with an experimentally derived coefficient $A=2 \times 10^{-6} \mathrm{~s}^{-1}$ (Sihto et al., 2006). Due to uncertainties in $A$, we carry out additional simulations with $A=2 \times 10^{-7} \mathrm{~s}^{-1}$ and $A=2 \times 10^{-5} \mathrm{~s}^{-1}$ to estimate the impact of uncertainties in the nucleation rate. Our test simulations show that activation nucleation produces unrealistically high particle concentrations in the free troposphere, and that this mechanism needs to be confined to the boundary layer; aircraft campaigns suggest that above the boundary layer particle concentrations have a minimum (Schroder, 2002) which would not be obtained by letting activation nucleation take place throughout the troposphere. Indeed, just above the boundary layer new particle formation appears to be rare. As shown in Fig. 1, the mechanistic restriction of activation nucleation produces a minimum in the particle concentrations above the boundary layer. While we do not argue that there are two separate nucleation mechanisms taking place in the atmosphere (there can be one or many), our approach leads to a phenomenologically justifiable representation of two different nucleation zones in the atmosphere consistent with observations. In this paper we refer to binary homogeneous nucleation as upper tropospheric nucleation (UTN) and activation nucleation as boundary layer nucleation (BLN). Different modeled nucleation schemes are summarised in Table 1.

\subsection{Model experiments}

The starting point of our analysis is the GLOMAP aerosol model with "standard" emissions and nucleation parameterizations described in Table 1. The standard emission scheme is similar to that used in our previous work (Spracklen et al., 2008) but now includes a source of ultrafine sea-salt (Martensson et al., 2003). This model is in satisfactory agreement with a large set of continental ground-level CN measurements and their seasonal variation (Spracklen et al.,
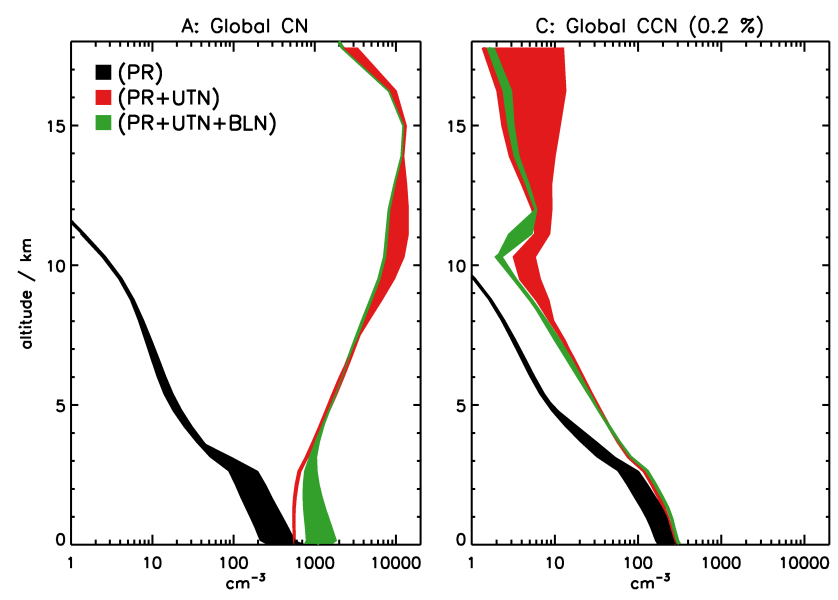

Fig. 1. Vertical STP volume averaged global aerosol concentrations of primary particles (black), primary particles and upper tropospheric nucleation (red), and primary particles, upper tropospheric nucleation and boundary layer nucleation (green). Shaded black, red, and green areas represent uncertainties in the obtained profiles due to uncertainties in primary emission size distribution, upper tropospheric nucleation rate, and boundary layer nucleation rate, respectively. A: Concentrations of all particles larger than $3 \mathrm{~nm}$ in diameter. B: CCN concentrations with $0.2 \%$ supersaturation.

2006, 2009), and with somewhat more limited measurements of $\mathrm{CCN}$ and CDNC in various environments (Spracklen et al., 2008; Merikanto et al., 2009). We calculate the relative contribution from primary particles and two nucleation mechanisms and study the uncertainties in each of these mechanisms by modifying emissions or processes with respect to their standard representation.

Combinations of model experiments were carried out to obtain the relative contribution from primary particles (PR), upper tropospheric nucleation (UTN), and boundary layer nucleation $(\mathrm{BLN})$ to particle number concentrations:

1. PR: Runs with only primary particles from particulate emissions with and without ultrafine sea-salt. We can calculate the contribution of ultrafine sea-salt to $\mathrm{CN}$ and $\mathrm{CCN}$ from these runs.

2. PR+UTN: Runs with particulate emissions (without ultrafine sea-salt) and UTN represented with the BHN (Kulmala et al., 1998) nucleation parameterization.

3. PR+UTN+BLN: Runs with particulate emissions (without ultrafine sea-salt), UTN represented with BHN (Kulmala et al., 1998), and BLN represented by the activation nucleation parameterization (Kulmala et al., 2006).

These simulations were carried out by running the model over the full year 2000 with 3-month spin-ups. 
Sensitivity simulations were carried out using shorter 1month runs for April 2000, including a 3-month model spinup:

4. Uncertainties in UTN rates were tested with $P R+U T N$ runs with BHN according to Vehkamäki et al. (2002) instead of Kulmala et al. (1998).

5. Uncertainties in primary particle concentrations were tested in PR+UTN runs with EC/OC primary particle concentrations raised by a factor of 8 (to represent a factor 2 uncertainty in particles sizes for fixed emission mass, similar to Spracklen et al. (2009)).

6. Uncertainties in boundary layer nucleation rates were tested in PR+UTN+BLN runs by raising and lowering the nucleation rate coefficient $A$ in Eq. (1) by a factor of 10.

The contribution of primary emissions and the two nucleation mechanisms was calculated from the differences between various runs. The competition between mechanisms may make the order of these calculations important. For example, effective $3 \mathrm{~nm}$ BLN rates are known to be limited by the condensation sink of the background aerosol (see Eq. 2), so the BLN contribution to $\mathrm{CN}$ and $\mathrm{CCN}$ needs to be calculated against the background of the pre-existing aerosol. From the above runs we calculate the BLN contribution as a particle excess according to

$(\mathrm{PR}+\mathrm{UTN}+\mathrm{BLN})-(\mathrm{PR}+\mathrm{UTN})=(\mathrm{BLN})$.

Maximum and minimum ranges of the contribution can also be calculated from the sensitivity runs. On the other hand, nucleation has only a minor effect on primary particles due to small and opposite changes in condensational and coagulational mass fluxes. Therefore, the contribution of primary particles can be obtained from the run with particulate emissions only, PR.

Our simulations show that total particle concentration in the upper troposphere is not very sensitive to BLN (Fig. 1) because there is very little background aerosol from BLN. The excess contribution from UTN is therefore obtained from

$(\mathrm{PR}+\mathrm{UTN}+\mathrm{BLN})-(\mathrm{BLN})-(\mathrm{PR})=(\mathrm{UTN})$,

so that summing PR, UTN and BLN gives the total concentrations exactly. This allows us to calculate the relative contributions to $\mathrm{CN}$ and $\mathrm{CCN}$ from each mechanism.

A third set of simulations was carried out to explore how different mechanisms compete. The interactions between particles through coagulation complicates assessment of the relative importance of each mechanism to particle concentrations. Particles lose their origin in coagulation with other particles and "real" atmospheric particles contain components from different production mechanisms. Changes in particulate emissions therefore result in nonlinear changes in nucleation rates, growth rates and particle size distribution because primary particles act as a coagulation sink for nucleated particles and a condensation sink for nucleating and condensing vapors (Spracklen et al., 2006). Two additional experiments were carried out to test how atmospheric concentrations respond to turning off each of the three production mechanisms in a different order to that used in the annual runs:

7. PR+BLN: Runs with standard primary emissions (without ultrafine sea-salt) and BLN nucleation using $A=2 \times 10^{-6} \mathrm{~s}^{-1}$. This run examines the effect of UT nucleation on boundary layer nucleation and is complementary to runs 2 and 3 .

8. UTN+BLN: Runs with UTN represented with Kulmala et al. (1998) parameterization and BLN using $A=2 \times 10^{-6} \mathrm{~s}^{-1}$. The run involves a hypothetical removal of all primary particle emissions. The $2.5 \%$ fraction of sulfur, normally emitted as primary sulfate, is emitted as $\mathrm{SO}_{2}$. This run examines the effect of primary emissions on nucleation.

These runs were carried out for April 2000 with 3-month spin-ups.

\section{Results}

\subsection{Global contributions and uncertainty estimates}

The simulated global mean vertical profiles of $\mathrm{CN}$ and CCN $(0.2 \%)$ for primary particles are shown in Fig. 1 with the associated uncertainties in emitted size distribution (see Table 1) indicated by the black shaded region (runs 1 and 5). The red areas in Fig. 1 show the resulting profile with primary emissions and upper tropospheric nucleation with the range showing the effect of using two different $\mathrm{H}_{2} \mathrm{SO}_{4}-\mathrm{H}_{2} \mathrm{O}$ nucleation formulations (runs 2 and 4). The smaller concentrations produced by $\mathrm{H}_{2} \mathrm{SO}_{4}-\mathrm{H}_{2} \mathrm{O}$ nucleation are obtained with the Kulmala et al. (1998) parameterization and higher concentrations with the Vehkamäki et al. (2003) parameterization. Finally, the green areas show the profile with standard primary particle emissions, upper tropospheric nucleation using the Kulmala et al. (1998) parameterization, and boundary layer nucleation represented with varying rates of activation nucleation (runs 3 and 6). Variations in the UTN rate result in only modest variations in boundary layer UTN contributions to $\mathrm{CN}$ and $\mathrm{CCN}(0.2 \%)$, and variations in BLN or primary emissions are most visible in the boundary layer concentrations.

Primary particle concentrations drop exponentially from $\sim 300 \mathrm{~cm}^{-3}$ at the surface (where they are emitted) to $\sim 100 \mathrm{~cm}^{-3}$ at the top of the boundary layer, and only few 
primary particles reach the upper troposphere. However, aircraft measurements show that total particle number concentrations can be very high in the upper troposphere (Twohy et al., 2002). In our model, UTN actively takes place below the tropopause, and total particle concentrations in the run including primary emissions and UTN increase exponentially above the boundary layer to reach $10^{4} \mathrm{~cm}^{-3}$. These nucleated particles become mixed through the atmospheric column by convective and large scale processes. Thus, although UTN particles have their source well above the surface the model suggests that their annual global mean total concentration actually exceeds primary particles in the boundary layer. While particles originating from UTN mix downwards they also grow, and the obtained $\mathrm{CCN}(0.2 \%)$ concentrations show an opposing trend to $\mathrm{CN}$, increasing with decreasing altitude. But even with UTN the ground level $\mathrm{CN}$ concentrations in the model are often far less than observed (Spracklen et al., 2006, 2009), and BLN needs to be included to match the observations. BLN increases both the $\mathrm{CN}$ and $\mathrm{CCN}(0.2 \%)$ concentrations in the boundary layer. BLN causes a minor reduction of $\mathrm{CN}$ and $\mathrm{CCN}$ above $\sim 5 \mathrm{~km}$. The resulting reduction is due to enhanced condensation of sulfuric acid and secondary organics on boundary layer particles. Hence less sulfuric acid and secondary organics are transported to UT where they would contribute to nucleation (sulfuric acid) and subsequent particle growth (sulfuric acid and secondary organics).

Figures 2, 3 and 4 show the contributions of different mechanisms to $\mathrm{CN}, \mathrm{CCN}(0.2 \%)$ and $\mathrm{CCN}(1.0 \%)$ as global, continental and marine means. The mean values were obtained from runs including ultrafine sea-salt, UTN represented with the sulfuric acid-water nucleation parameterization of Kulmala et al. (1998), and BLN using an activation coefficient $A=2 \times 10^{-6}$. The ranges, indicated by horizontal bars, show the effect of combined uncertainties in each mechanism (see Table 1).

On a global scale, primary particles account for roughly one-quarter of ground level CN (range 16-63\%) with all other particles being derived from nucleation. Globally, a quarter of ground level CN originate from UTN (range 13$39 \%$ ), and approximately half of the $\mathrm{CN}$ originate from BLN (range 15-68\%). In contrast, low-level cloud CCN (0.2\%) (460-1100 $\mathrm{m}$ above ground level) is dominated by primary particles (51-69\%), while UTN produces roughly one-third (25-39\%) and BLN one-tenth (4-13\%) of low-level cloud $\mathrm{CCN}(0.2 \%)$. However, because the size spectrum of small particles is dominated by nucleated particles the relative contribution of nucleation to $\mathrm{CCN}$ is greater at higher supersaturation since smaller particles can be activated. For CCN (1.0\%), one-half originates from primary particles (33-63\%), UTN still contributes one-third (26-48\%), but the BLN contribution increases to one-fifth $(8-28 \%)$. Primary particle and BLN contributions to total particle concentrations fall rapidly with height, and nearly all particles above $5 \mathrm{~km}$ originate from UTN. However, the few remain- ing primary particles above the boundary layer act as $\mathrm{CCN}$ more effectively than UTN particles and their contribution to CCN (0.2\%) at $6 \mathrm{~km}$ is still $25 \%$ as a global mean or $40 \%$ over continental regions. Also BLN particles that penetrate through the boundary layer have become larger, and activate more easily than UTN particles above the boundary layer.

BLN produces fewer particles over oceans than over continents, but its relative contribution to $\mathrm{CN}$ and $\mathrm{CCN}$ is nearly equal over the global marine and continental boundary layers. The contribution of primary particles to boundary layer $\mathrm{CN}$ and $\mathrm{CCN}$ is larger over continents than over marine regions, and primaries dominate continental $\mathrm{CCN}$ regardless of supersaturation or uncertainties in the analysis. In marine regions, however, UTN produces the same number of $\mathrm{CCN}(0.2 \%)$ as primary particles and dominates marine boundary layer $\mathrm{CCN}(1.0 \%)$.

\subsection{Regional contributions to $\mathrm{CN}$}

Figure 5 shows the ground level $\mathrm{CN}$ concentrations in different regions and the contribution to $\mathrm{CN}$ from each mechanism (as a mean over year 2000). Highest primary CN occurs over the continents where anthropogenic emissions and forest fires are the major contributors. Over marine regions primary particles originate mostly from oceanic sea-salt.

UTN produces particles that have a long life time. These particles can travel long distances with the general circulation, resulting in a fairly uniform ground-level global distribution ranging from $\sim 50 \mathrm{~cm}^{-3}$ in the Arctic to $>800 \mathrm{~cm}^{-3}$ in the sub-tropics. The dominant spatial pattern of ground level $\mathrm{CN}$ from UTN is zonal, with peak inputs in the sub-tropics $\pm 30^{\circ}$ from the equator (Fig. $5 \mathrm{~b}$ ), where the air descends from the free troposphere in the Hadley cell with limited scavenging. Elevated regions, such as the Himalayas, have higher than average particle concentrations from UTN simply because they are closer to the UT. This simple spatial pattern of $\mathrm{CN}$ from UTN shows very little memory of the much more patchy sources of the precursor gas $\mathrm{SO}_{2}$.

BLN is the most important contributor to the global ground level $\mathrm{CN}$. Highest particle concentrations of several thousand per cubic centimeter from BLN occur over the continents, but not always in the regions with highest pollution or sulfur emissions. Some BLN is also observed over the marine regions where $\mathrm{SO}_{2}$ emissions from shipping or DMS emissions from phytoplankton are high. BLN produces relatively few particles in equatorial regions, except along some shipping tracks and near volcanic sulfur sources.

The different spatial strengths of particle production mechanisms make their regional contributions very different from the global mean. Figure 6 shows the relative regional contributions to $\mathrm{CN}$ from each mechanism. Values over specific regions are listed in Table 2. In marine regions the importance of the flux of nucleated particles from the upper troposphere is enhanced due to weaker primary emissions compared to the continents. The UTN source is particularly 

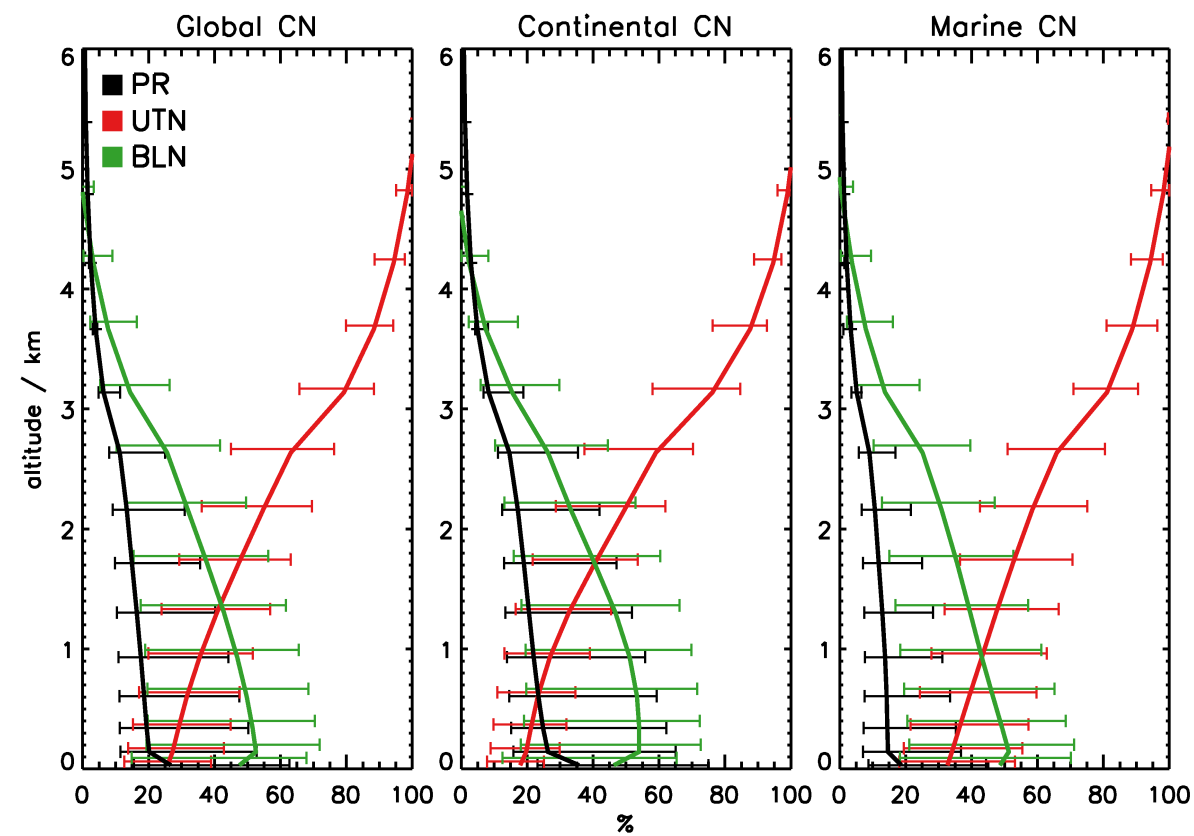

Fig. 2. Vertical contribution of boundary layer nucleation (green), upper tropospheric nucleation (red), and primary OC, BC, sulphate and sea salt particles (black) to A: global; B: continental; C: marine total volume averaged particle concentrations (all particles larger than $3 \mathrm{~nm}$ ). Horizontal bars represent combined uncertainties in each mechanism.
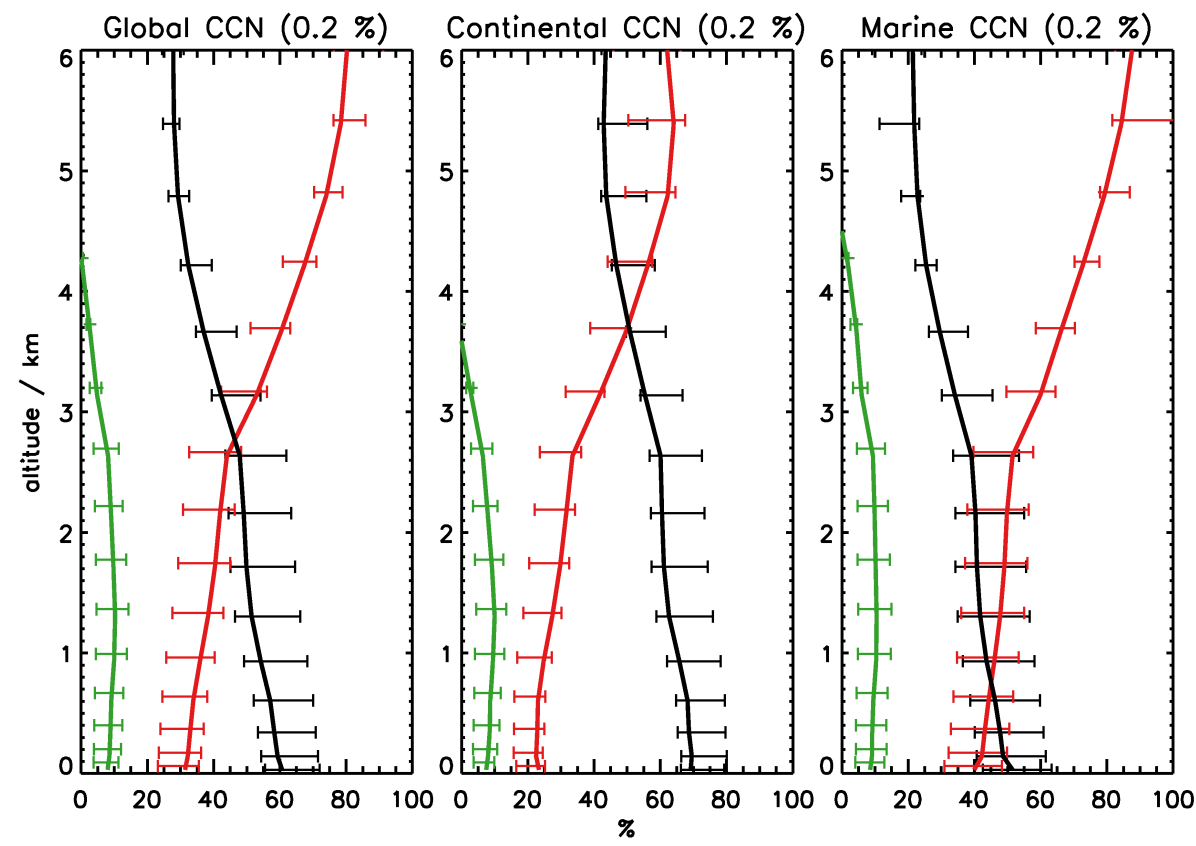

Fig. 3. Vertical contribution of boundary layer nucleation (green), upper tropospheric nucleation (red), and primary particles (black) to A: global; B: continental; C: marine cloud condensation nuclei volume averaged concentrations at $0.2 \%$ supersaturation with associated uncertainties. 

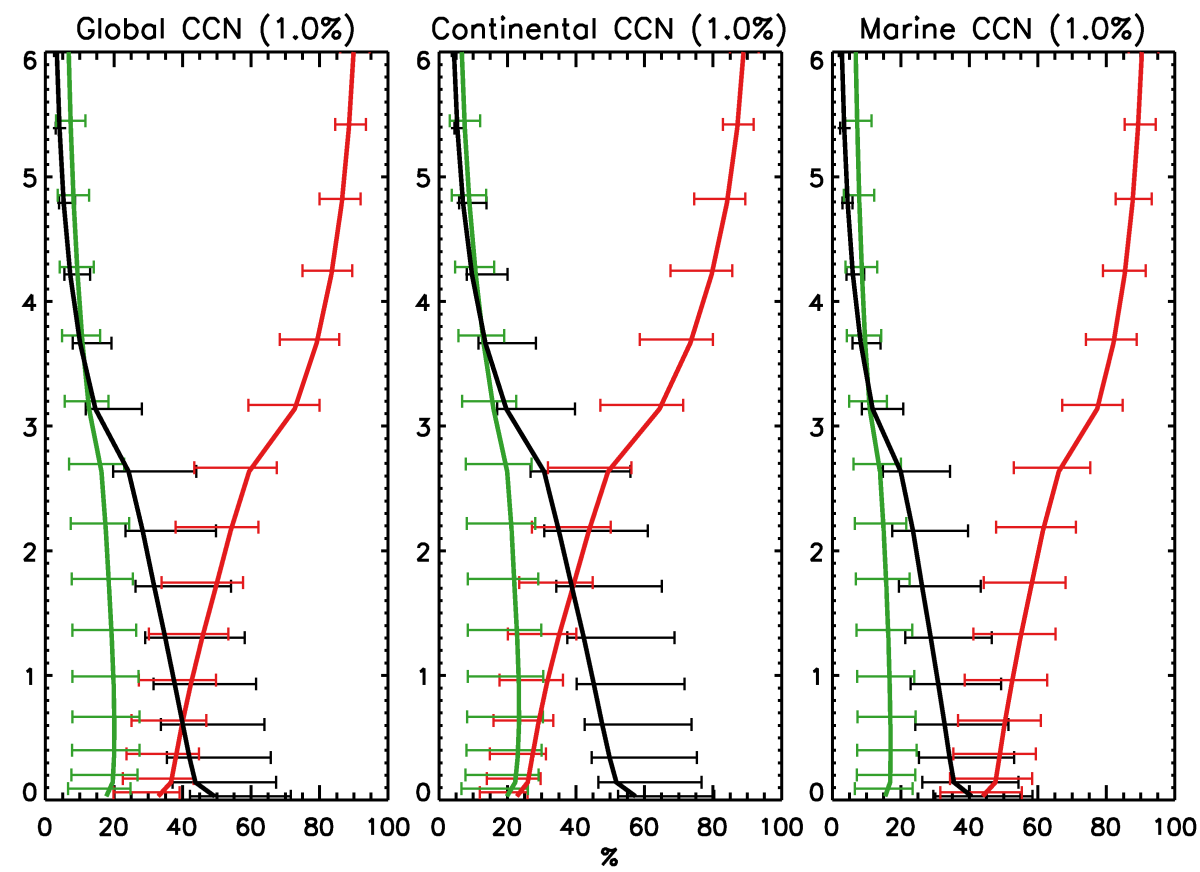

Fig. 4. Vertical contribution of boundary layer nucleation (green), upper tropospheric nucleation (red), and primary particles (black) to A: global; B: continental; C: marine cloud condensation nuclei concentrations with $1.0 \%$ supersaturation, and combined uncertainties in each mechanism.

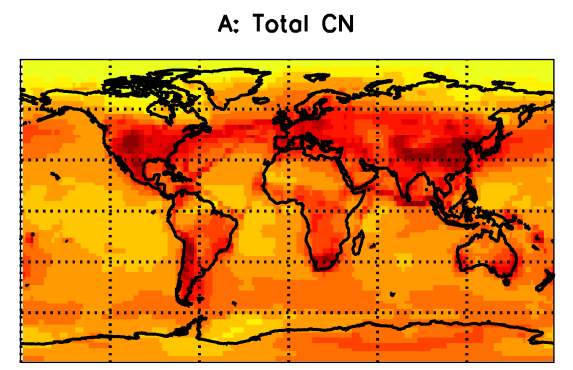

B: $\mathrm{CN}$ from Primaries

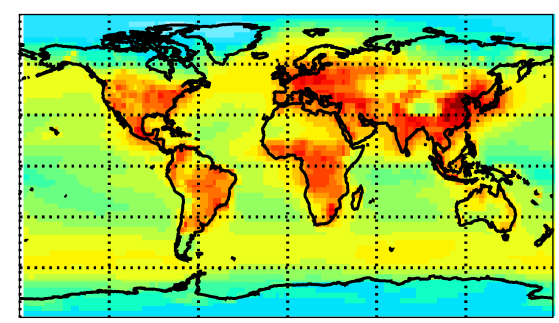

$110100100010000 \mathrm{~cm}^{-3}$

C: CN from UTN

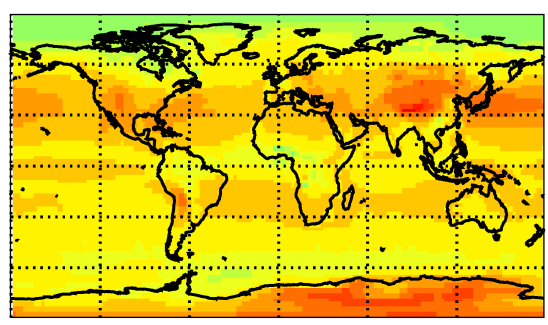

$110100100010000 \mathrm{~cm}^{-3}$

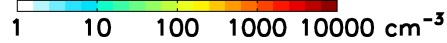

$D: C N$ from BLN

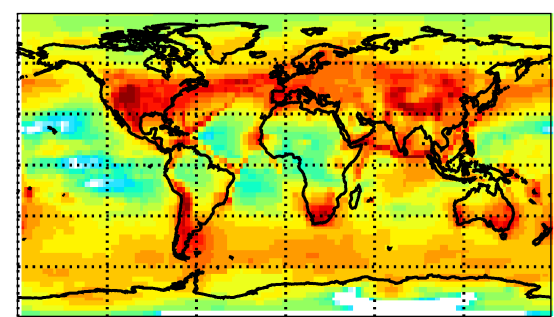

$110100100010000 \mathrm{~cm}^{-3}$

Fig. 5. Ground level total particle (above $3 \mathrm{~nm}$ in diameter) average concentrations of A: all particles (sum of panels $\mathbf{B}, \mathbf{C}$ and $\mathbf{D}$ ); B: primary particles; C: nucleated particles entrained from upper troposphere; D: particles nucleated in the boundary layer. 
A: $\mathrm{CN}$ contribution from nucleation

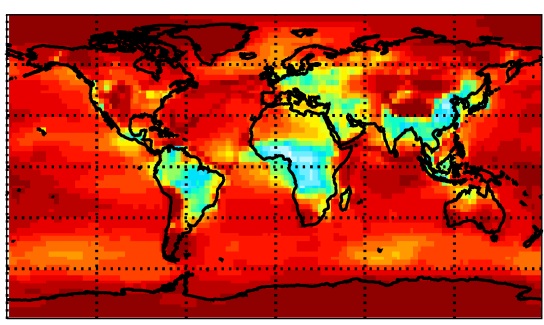

$\begin{array}{llllll}0 & 25 & 50 \quad 75 & 100 & \%\end{array}$

C: $\mathrm{CN}$ contribution from UTN

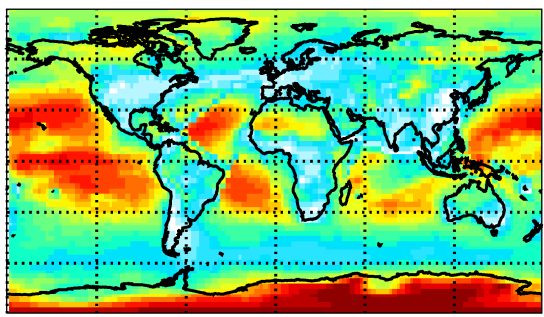

$0 \quad 25 \quad 50 \quad 75 \quad 100 \%$
B: $\mathrm{CN}$ contribution from Primaries

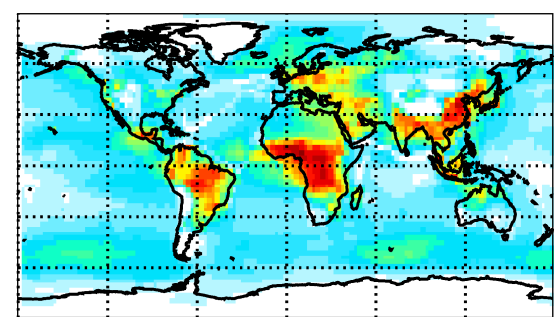

\begin{tabular}{lllll}
\hline & 25 & 50 & 75 & 100
\end{tabular}

D: $\mathrm{CN}$ contribution from BLN
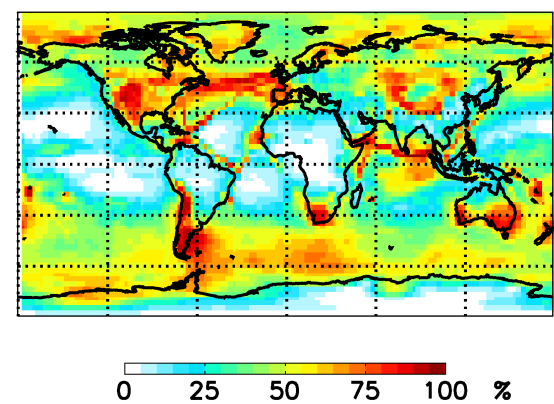

Fig. 6. Relative average contributions to ground total particle concentrations (above $3 \mathrm{~nm}$ in diameter) of $\mathbf{A}$ : all nucleation particles (sum of panels $\mathbf{C}$ and D); B: primary particles; C: upper tropospheric nucleated particles; D: boundary layer nucleated particles.

important (>80\%) in regions of low wind speed such as the sub-tropics. In equatorial regions primaries dominate the continental $\mathrm{CN}$ and UTN dominates the marine $\mathrm{CN}$. In marine regions the relative contribution of primaries appears to be relatively constant, while UTN and BLN show opposite patterns. This suggests that particles from UTN are limiting BLN in several marine regions (see Sect. 3.4).

\subsection{Regional contributions to $\mathrm{CCN}$}

Regional CCN $(0.2 \%)$ concentrations, calculated for clouds at $460-1100 \mathrm{~m}$ above ground level, are shown in Fig. 7 for all particles and for particles produced by each mechanism. While the continental $\mathrm{CN}$ patterns are dominated by BLN particles, continental CCN $(0.2 \%)$ patterns are dominated by primary particles. Marine $\mathrm{CCN}(0.2 \%)$ concentrations from primary particles are elevated in coastal regions due to particle outflow, and in regions of high wind speed with strong sea-salt emissions as in the Southern Ocean.

The CCN concentrations from UTN are rather uniform over different longitudes and vary between $<30 \mathrm{~cm}^{-3}$ in the Arctic to $>300 \mathrm{~cm}^{-3}$ in the sub-tropics and over some midlatitude continental regions. The enhancement in absolute $\mathrm{CCN}$ concentrations from UTN over some continental regions is due to biogenic organic vapors and sulfate that grow the entrained particles effectively. For example, over eastern Amazonia the UTN CN and CCN concentrations are approx- imately equal, showing that most entrained $\mathrm{CN}$ are effective CCN.

The regional distribution of CCN produced by BLN is very different from the corresponding $\mathrm{CN}$ distribution shown in Fig. 5d. BLN produces large concentrations of particles in Chile from volcanic $\mathrm{SO}_{2}$ and only a few particles in the Amazon, but produces almost no CCN in Chile. This difference in the distribution of $\mathrm{CN}$ and $\mathrm{CCN}$ from BLN highlights the importance of horizontal transport of BLN particles and the importance of secondary organics (which are higher over the Amazon) in their growth. Over the Southern Ocean BLN produces large concentrations of $\mathrm{CN}$, but the contribution to $\mathrm{CCN}$ is small and requires a large supersaturation.

Figures 8 and 9 show the relative contributions of all nucleated particles (UTN and BLN), primary particles, and BLN and UTN separately to CCN (0.2\%) and CCN (1.0\%). Primary particles dominate $\mathrm{CCN}$ in polluted regions and regions with biomass burning: central European, SouthEast Asia, central Africa, South America, and the Southern Ocean. $\mathrm{CCN}$ in the Arctic, northern North America, northern Asia, and over almost all marine sub-tropical regions are dominated by nucleated particles. In particular, in marine sub-tropical regions that are distant from continental primary sources and that have low sea-salt emissions, boundary layer $\mathrm{CCN}$ are mostly entrained from the upper troposphere.

The upper troposphere makes a large contribution to boundary layer $\mathrm{CCN}$ in the Arctic. Although the absolute source strengths are low from all mechanisms in the Arctic, 
A: Total CCN (0.2\%)

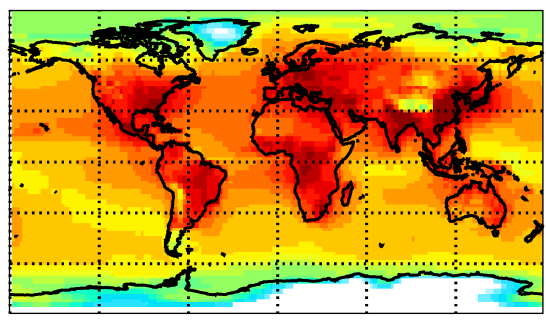

$16442992000 \mathrm{~cm}^{-3}$

C: $\operatorname{CCN}(0.2 \%)$ from UTN

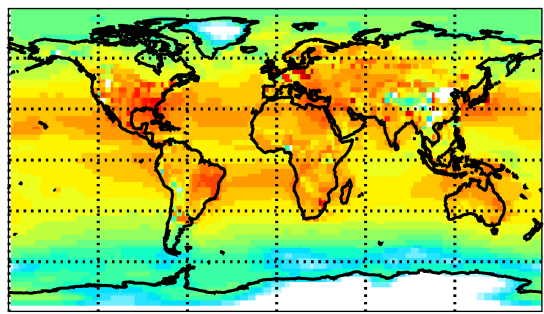

$16442992000 \mathrm{~cm}^{-3}$
B: $\operatorname{CCN}(0.2 \%)$ from Primaries

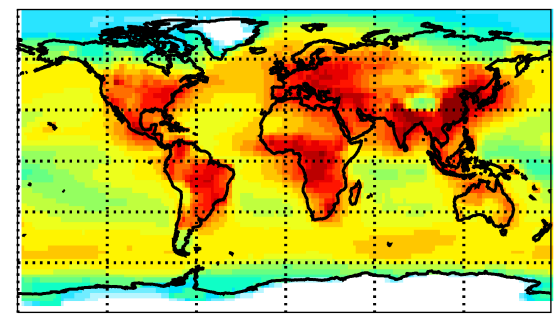

$16442992000 \mathrm{~cm}^{-3}$

$D: \operatorname{CCN}(0.2 \%)$ from BLN

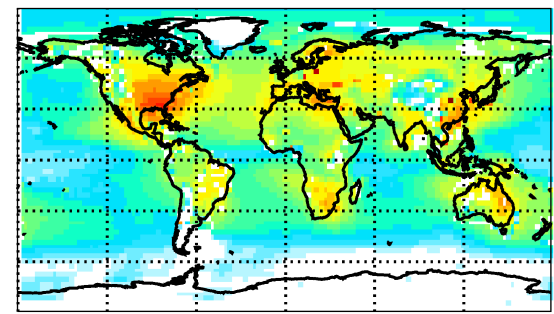

$1 \quad 6 \quad 442992000 \mathrm{~cm}^{-3}$

Fig. 7. Average cloud condensation nuclei concentrations with $0.2 \%$ supersaturation at $460-1100 \mathrm{~m}$ above ground level of A: all particles (sum of panels B, C and D); B: primary particles; C: nucleated particles entrained from upper troposphere; D: particles nucleated in the boundary layer.

A: $\operatorname{CCN}(0.2 \%)$ contribution from nucleation

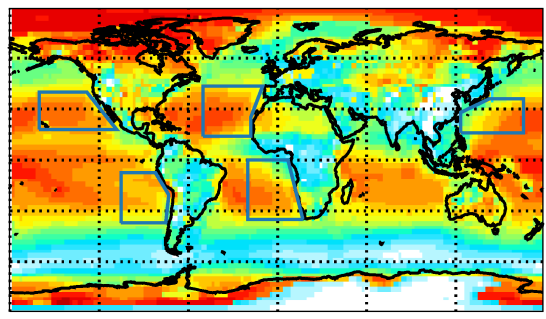

$0 \quad 25 \quad 50 \quad 75 \quad 100 \%$

C: $\operatorname{CCN}(0.2 \%)$ contribution from UTN

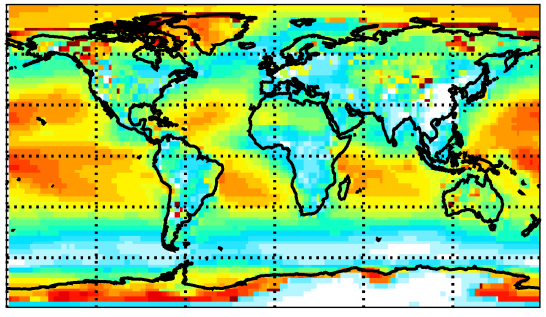

\begin{tabular}{llll}
\hline & $25 \quad 50 \quad 75$ & $100 \%$
\end{tabular}
B: $\operatorname{CCN}(0.2 \%)$ contribution from Primaries
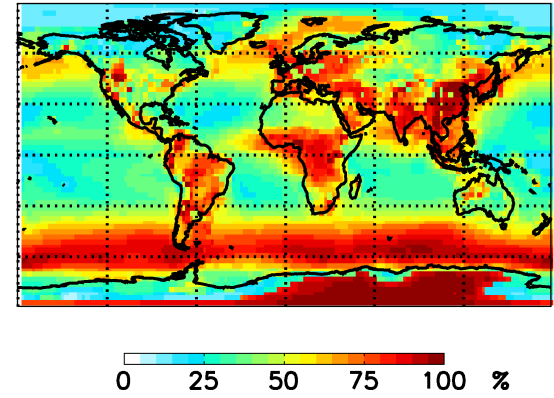

D: $\operatorname{CCN}(0.2 \%)$ contribution from BLN

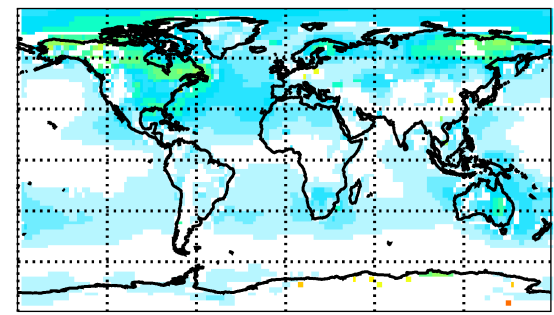

$0 \quad 25 \quad 50 \quad 75 \quad 100 \%$

Fig. 8. Relative average contributions to cloud condensation nuclei concentrations at $460-1100 \mathrm{~m}$ above ground level with $0.2 \%$ supersaturation of $\mathbf{A}$ : all nucleation particles (sum of panels $\mathbf{C}$ and $\mathbf{D}$ ). Regions with persistent stratocumulus decks are highlighted with blue lines; $\mathbf{B}$ : primary particles; C: upper tropospheric nucleated particles; D: boundary layer nucleated particles. 
Table 2. Summary of contributions of primary particles (PR), boundary layer nucleation (BLN) and upper tropospheric nucleation (UTN) to concentrations of all particles $(\mathrm{CN})$ at ground level and cloud condensation nuclei $(\mathrm{CCN})$ at $460-1100 \mathrm{~m}$ above ground level at $0.2 \%$ and $1.0 \%$ supersaturations. The values correspond to results obtained with the standard scheme in Table 1. The total average concentrations are also shown. The marine regions refer to west of North America (NAM), west of South America (SAM), west of North Africa (NAF), west of South Africa (SAF), and East of North-East Asia (NEA) (see Figs. 8 and 9).

\begin{tabular}{lcccccc}
\hline & \multicolumn{2}{c}{ CN } & \multicolumn{2}{c}{ CCN $(1.0 \%)$} & \multicolumn{2}{c}{ CCN $(0.2 \%)$} \\
Region & All $\left[\mathrm{cm}^{-3}\right]$ & PR-UTN-BLN [\%] & All $\left[\mathrm{cm}^{-3}\right]$ & PR-UTN-BLN [\%] & All [cm $\left.{ }^{-3}\right]$ & PR-UTN-BLN [\%] \\
\hline Total Global & 1063 & $27-26-48$ & 430 & $39-41-20$ & 263 & $55-35-10$ \\
Total Marine & 778 & $19-33-49$ & 308 & $32-51-17$ & 187 & $45-45-10$ \\
NAM & 599 & $20-63-18$ & 380 & $22-68-9$ & 251 & $30-60-10$ \\
SAM & 567 & $14-41-45$ & 231 & $26-63-12$ & 145 & $35-57-8$ \\
NAF & 1007 & $12-31-57$ & 397 & $22-59-20$ & 261 & $30-53-17$ \\
SAF & 616 & $23-41-36$ & 343 & $37-52-11$ & 260 & $46-46-7$ \\
NEA & 1402 & $35-35-30$ & 745 & $44-43-13$ & 507 & $58-33-9$ \\
Total Continental & 1813 & $36-18-46$ & 754 & $46-30-23$ & 461 & $67-24-9$ \\
Europe & 2640 & $47-11-42$ & 1201 & $49-21-30$ & 680 & $69-19-12$ \\
Africa & 1170 & $50-20-29$ & 714 & $57-29-14$ & 548 & $70-24-6$ \\
N. America & 2496 & $20-12-69$ & 894 & $27-29-44$ & 398 & $53-27-20$ \\
S. America & 1595 & $36-15-49$ & 632 & $54-32-13$ & 469 & $67-26-6$ \\
N. Asia & 1149 & $22-26-53$ & 531 & $28-41-30$ & 251 & $51-36-13$ \\
S.E. Asia & 3954 & $46-14-40$ & 1395 & $59-23-18$ & 862 & $81-14-5$ \\
Oceania & 1303 & $21-20-59$ & 573 & $29-41-30$ & 321 & $48-36-16$ \\
Antarctica & 755 & $2-76-22$ & 91 & $14-71-16$ & 5 & $31-65-4$ \\
\hline
\end{tabular}

A: $\operatorname{CCN}(1.0 \%)$ contribution from nucleation

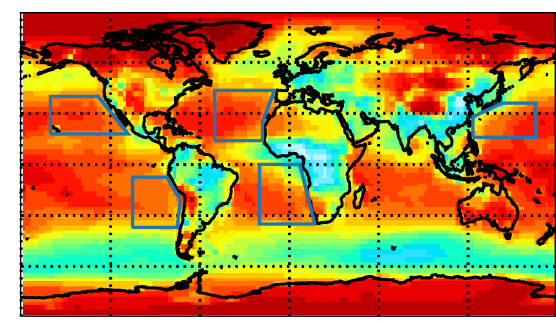

\begin{tabular}{lllll}
\hline & 25 & 50 & 75 & 100
\end{tabular}

C: CCN (1.0\%) contribution from UTN

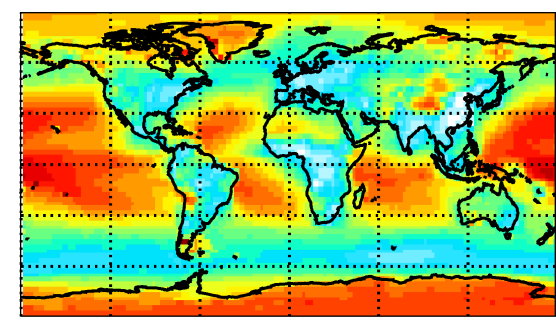

\begin{tabular}{lllll}
\hline 0 & 25 & 50 & 75 & 100
\end{tabular}
B: $\operatorname{CCN}(1.0 \%)$ contribution from Primaries

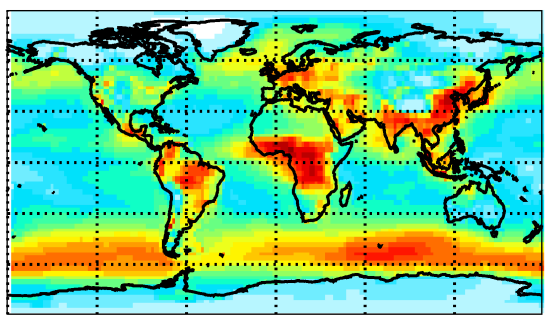

\begin{tabular}{lllll}
\hline 0 & 25 & 50 & 75 & 100
\end{tabular}

D: $\operatorname{CCN}(1.0 \%)$ contribution from BLN

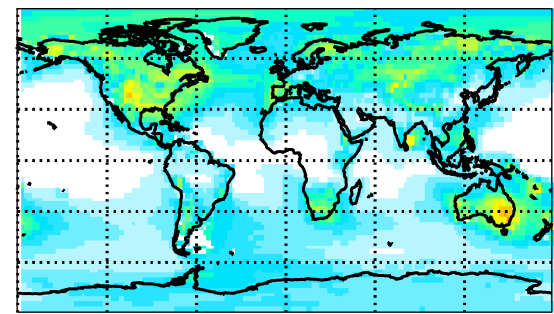

\begin{tabular}{lllll}
\hline & 25 & 50 & 75 & 100
\end{tabular}

Fig. 9. Relative average contributions to cloud condensation nuclei concentrations at $460-1100 \mathrm{~m}$ above ground level with $1.0 \%$ supersaturation of $\mathbf{A}$ : all nucleation particles (sum of panels $\mathbf{C}$ and $\mathbf{D}$ ). Regions with persistent stratocumulus decks are highlighted with blue lines; $\mathbf{B}$ : primary particles; $\mathbf{C}$ : upper tropospheric nucleated particles; D: boundary layer nucleated particles. 
UTN is by far the most dominant CCN source there, contributing over $60 \%$.

In the figures we have marked the marine regions with persistent stratiform clouds. According to our results the majority ( $>60 \%$ ) of CCN in these cloudy regions originate from UTN.

The relative importance of boundary layer nucleation as a source of $\mathrm{CCN}$ is significantly less than it is for $\mathrm{CN}$, but BLN still enhances CCN (0.2\%) significantly in several continental regions ( $>30 \%$ ) and over the North Atlantic, and increasingly so at the higher supersaturation of $1 \%(>50 \%)$.

\subsection{Interactions between $\mathrm{CN}$ and $\mathrm{CCN}$ production mechanisms}

Understanding how different particle production mechanisms contribute to $\mathrm{CN}$ and $\mathrm{CCN}$ helps us to understand the spatial distribution of atmospheric particles. However, one should bear in mind that the mechanisms interact in a complex way. We tested how the $\mathrm{CN}$ and $\mathrm{CCN}$ concentrations changed by switching off the production mechanisms one at a time.

Switching off primary emissions completely in April 2000 (UTN+BLN, run 8) actually increases the global mean ground level $\mathrm{CN}$ by $31 \%$ (compared to run PR+UTN+BLN), while global mean CCN $(0.2 \%)$ in low-level clouds decreases by $20 \%$. Therefore, primary emissions as a whole suppress total particle concentrations but enhance CCN. In Spracklen et al. (2006) we showed that there is a non-linear relationship between primary emission strength and total particle concentration. A small reduction in primary emissions decreases the global total particle concentration, but after some point the total particle concentration starts increasing as nucleation becomes more effective (with reducing condensation/coagulation sink).

The relationship between primary emissions and $\mathrm{CCN}$ is different over continental and marine regions. Over the continents primary particles contribute $59 \%$ of $\mathrm{CCN}(0.2 \%)$ in low-level clouds in April 2000 and their switch-off reduces $\mathrm{CCN}(0.2 \%)$ by $33 \%$, whereas primary emissions can explain $44 \%$ of marine $\mathrm{CCN}(0.2 \%)$ but their switch-off reduces $\mathrm{CCN}(0.2 \%)$ by $16 \%$. Therefore, the primary emissions restrict the production of $\mathrm{CCN}(0.2 \%)$ via nucleation over the oceans more than over land.

In this atmosphere without primary emissions $50 \%$ of the global CCN $(0.2 \%)$ in low-level clouds come from BLN and $50 \%$ from UTN. This is quite a different split between BLN and UTN compared to the atmosphere with primary emissions, in which nearly $73 \%$ of the nucleated CCN came from UTN. Thus, primary emissions, which are primarily anthropogenic in origin, strongly suppress the importance of BLN as a source of CCN. This sensitivity of nucleation to primary emissions suggests that future increases in marine boundary layer $\mathrm{CCN}$ due to higher wind speeds and greater sea-salt emissions would not scale linearly with the changes in emis- sions. It also suggests that the sources of $\mathrm{CCN}$ in pre-human conditions may be quite different to today.

Switching off UTN but leaving on BLN and primary emissions decreases the ground level $\mathrm{CN}$ by only $5 \%$, and $\mathrm{CCN}(0.2 \%)$ in low-level clouds by $12 \%$. The relatively small reduction compared to the estimated annual mean contribution of UTN to CN of $26 \%$ and CCN $(0.2 \%)$ of $41 \%$ (Table 2) is due to the response of BLN to the reduced aerosol input from the UT. In the absence of UTN, BLN starts taking place in regions of the marine boundary layer where it is not occurring when the background aerosol originating from upper troposphere was included. In this run without UTN, the global mean contribution of BLN to global mean lowlevel cloud CCN $(0.2 \%)$ is $48 \%$ (60\% marine mean), which is disproportionately larger than the $55 / 10 \%$ split between primary and BLN CCN $(0.2 \%)$ (45/10\% in marine atmosphere) when BLN is added to an atmosphere with UTN. Thus, UTnucleated particles are an important sink for boundary layernucleated particles, a response seen in early box model simulations (Raes, 1995; Raes et al. , 2000) but confirmed here as a global phenomenon. The sensitive balance between the production of BLN particles and their loss to the background aerosol means that the total CCN concentration is less than proportionally affected by changes in UT or primary particles.

\section{Conclusions and discussion}

Table 2 summarises the contributions of UTN, BLN and particulate emissions to global and regional ground level $\mathrm{CN}$, and $\mathrm{CCN}(0.2 \%)$ and $\mathrm{CCN}(1.0 \%)$ at the altitude of low-level clouds. The estimates are based on the GLOMAP model runs that produce best agreements with observed particle number concentrations and size distributions (Spracklen et al., 2008, 2009).

On a global mean, primary particles contribute $55 \%$ of CCN $(0.2 \%)$ and nucleation $45 \%$, from which $35 \%$ can be attributed to the flux of nucleated particles from the free and upper troposphere (UTN) and 10\% from boundary layer nucleation (BLN). However, these UTN particles also significantly suppress the $\mathrm{CCN}$ yield from BLN particles, whose contribution to $\mathrm{CCN}(0.2 \%)$ would be much larger if the UT source were suppressed.

The contribution of nucleation to $\mathrm{CCN}(0.2 \%)$ in low-level clouds is greater over marine regions $(55 \%)$ than over land areas $(33 \%)$. But even over the most polluted continental regions with high primary emissions, such as in South-East Asia, nucleation accounts for $19 \%$ of CCN $(0.2 \%)$. In contrast, some continental regions appear to be rather similar to marine regions in terms of the sources of CCN. For example, in northern Asia and North America nucleation contributes nearly half of all CCN $(0.2 \%)$.

At higher elevations the contribution of primary particles to $\mathrm{CCN}$ decreases and the contribution from UTN particles 
increases. Also with a larger in-cloud supersaturation the relative contribution of nucleation sources to $\mathrm{CCN}$ increases, as smaller particles dominated by nucleation sources become activated. Particularly this is the case for boundary layer nucleation. Globally, BLN contributes $10 \%$ of CCN $(0.2 \%)$ but $20 \%$ of CCN $(1.0 \%)$. This is because nucleation in the boundary layer contributes most to the small particle sizes: nearly half of all ground level particles above $3 \mathrm{~nm}$ are produced by BLN.

There are significant uncertainties in atmospheric nucleation mechanisms and in global primary particle emissions. The near-linear relationship of continental nucleation rates to sulfuric acid concentrations is nowadays fairly well established in a number of field experiments (Kulmala et al., 2008), but it remains unclear if this mechanisms depends on additional species besides sulfuric acid, such as on secondary organics (Laaksonen et al., 2008). Here, we have represented boundary layer nucleation with an activation scheme (Kulmala et al., 2006) using the same rate constants in all environments, but in reality boundary layer nucleation rates are observed to have larger temporal and spatial variation ( $\mathrm{Ri}-$ ipinen et al., 2007). Other nucleation mechanisms may also contribute to boundary layer nucleation: for example iodinedriven nucleation can be a significant source of new particles in coastal areas (O'Dowd and de Leeuw, 2007). We have represented nucleation in the upper troposphere with neutral binary homogeneous nucleation of sulfuric acid and water, but it is possible that ion-induced nucleation can be the dominant source in UT and possibly significantly contributes to boundary layer nucleation as well (Lovejoy et al., 2004; Kazil et al., 2006; Yu et al., 2008). Uncertainties are also related to the yield of condensing secondary organic vapor, which can modify the obtained aerosol size distributions considerably (Spracklen et al., 2008) and enhance the particle growth rates to $\mathrm{CCN}$ sizes. Primary organic emission strengths are still somewhat uncertain (Bond et al., 2004), and the proportion of sulfur emissions that directly produces sulfate anticorrelates strongly with BLN aerosol production capability (Wang and Penner, 2009). While we take some of these uncertainties into account, an exhaustive analysis of all uncertainties is currently not possible.

In the current analysis we have used three different scenarios for primary emissions, three different rate constants for boundary layer nucleation, and two different parameterizations of neutral binary homogeneous nucleation of sulfuric acid and water. The uncertainties were then combined using the minimum and maximum aerosol production yield from each production mechanism. Within this error analysis we can conclude that particles produced in the upper troposphere dominate both total particle number and CCN above the boundary layer and compete as a dominant source od $\mathrm{CCN}$ in the marine boundary layer with primary particles (mainly sea salt), and that continental boundary layer $\mathrm{CCN}$ is dominated by primary emissions.
The global spread of particles nucleated in the free and upper troposphere means that virtually nowhere on the planet escapes the influence of sulfate pollution. While sulfate pollution is strongly concentrated over and near to source regions, the CCN produced in the FT from these sulfur species are spread much more widely; the residence time of free tropospheric sulfate is estimated to be from a few weeks to over a month whereas it is only few days in the boundary layer (Rodhe, 1999; Williams et al., 2002). The general circulation patterns make the longitudinal transport of free tropospheric particles more efficient than latitudinal transport, and they enter the boundary layer fairly evenly over different longitudes regardless of continents. We have highlighted the marine stratocumulus decks where this long reach of nucleated $\mathrm{CCN}$ is important. The model results suggest that in many regions the $\mathrm{CCN}$ budget can be understood only in the context of long-range transport. Even in highly polluted regions $\mathrm{CCN}$ from long-range transport through the free troposphere make a non-negligible contribution.

These simulations have shown that nucleated particles are transported very large distances and can affect $\mathrm{CCN}$ in regions far from where precursor gases were emitted. The transport, transformation and removal processes are therefore important factors in shaping the global CCN distribution. While previous model intercomparisons and assessments have evaluated aerosol lifetimes on a mass basis, an evaluation of size-resolved transport efficiency and removal would be useful.

Our analysis has also shown how primary and nucleated $\mathrm{CCN}$ sources are non-linearly coupled. In particular, boundary layer nucleation is strongly suppressed both by primary emissions at the surface and by the influx of particles that were nucleated in the upper troposphere. This coupling means that in most regions $\mathrm{CCN}$ will respond nonlinearly to future changes in natural and anthropogenic primary emissions and condensable gases. For example, apart from $40^{\circ}-60^{\circ} \mathrm{S}$ Southern Ocean region, changes in marine $\mathrm{CCN}$ due to climate-induced changes in wind speed will not scale with sea spray emissions.

Acknowledgements. This work was supported by grants from NERC (AEROFORM NE/D01395X/1 and APPRAISE theme 3), a Royal Society International Joint Project, and the EU EUCAARI integrated project. J. Merikanto was also supported by Academy of Finland grant no. 131083.

Edited by: V.-M. Kerminen

\section{References}

Adams, P. J. and Seinfeld, J. H.: Predicting global aerosol size distributions in general circulation models, J. Geophys. Res., 107, 4370, doi:10.1029/2001JD001010, 2002.

Alfarra, M. R., Paulsen, D., Gysel, M., Garforth, A. A., Dommen, J., Prévôt, A. S. H., Worsnop, D. R., Baltensperger, U., and Coe, H.: A mass spectrometric study of secondary organic aerosols 
formed from the photooxidation of anthropogenic and biogenic precursors in a reaction chamber, Atmos. Chem. Phys., 6, 52795293, 2006, http://www.atmos-chem-phys.net/6/5279/2006/.

Benkovitz, C. M., Scholtz, M. T., Pacyna, J., Tarrason, L., Dignon, J., Voldner, E. C., Spiro, P. A., Logan, J. A., and Graedel, T. E.: Global gridded inventories of anthropogenic emissions of sulfur and nitrogen, J. Geophys. Res.-Atmos., 101(D22), 29239-29253, 1996.

Benson, D. R., Li-Hao Young, Shan-Hu Lee, Campos, T. L., Rogers, D. C., and Jensen, J.: The effects of airmass history on new particle formation in the free troposphere: case studies, Atmos. Chem. Phys., 8, 3015-3024, 2008, http://www.atmos-chem-phys.net/8/3015/2008/.

Bond, T., Streets, D. G., Yarber, K. F., Nelson, S. M., Woo, J.H., and Klimont, Z.: A technology-based global inventory of black and organic carbon emissions from combustion, J. Geophys. Res.-Atmos., 109, D14203, doi:10.1029/2003JD003697, 2004.

Bonn, B., Kulmala, M., Riipinen, I., Sihto, S.-L., and Ruuskanen, T. M.: How biogenic terpenes govern the correlation between sulfuric acid concentrations and new particle formation, J. Geophys. Res., 113, D12209, doi:10.1029/2007JD009327, 2008.

Chipperfield, M.: New version of the TOMCAT/SLIMCAT offline chemical transport model: Intercomparison of stratospheric tracer experiments, Q. J. Roy. Meteor. Soc., 132, 1179-1203, doi:10.1256/qj.05.51, 2006.

Clarke, A. D., Owens, S., and Zhou, J.: An ultrafine seasalt flux from breaking waves: Implications for $\mathrm{CCN}$ in the remote marine atmosphere, J. Geophys. Res. Atmos., 111, D06202, doi:10.1029/2005JD006565, 2006.

Dentener, F., Kinne, S., Bond, T., Boucher, O., Cofala, J., Generoso, S., Ginoux, P., Gong, S., Hoelzemann, J. J., Ito, A., Marelli, L., Penner, J. E., Putaud, J.-P., Textor, C., Schulz, M., van der Werf, G. R., and Wilson, J.: Emissions of primary aerosol and precursor gases in the years 2000 and 1750 prescribed data-sets for AeroCom, Atmos. Chem. Phys., 6, 4321-4344, 2006, http://www.atmos-chem-phys.net/6/4321/2006/.

Fountoukis, C., Nenes, A., Meskhidze, N., Bahreini, R., Conant, W. C., Jonsson, H. Murphy, S., Sorooshian, A., Varutbangkul, V., Brechtel, F., Flagan, R. C., and Seinfeld J. H.: Aerosol-cloud drop concentration closure for clouds sampled during the International Consortium for Atmospheric Research on Transport and Transformation 2004 campaign, J. Geophys. Res., 112, D10S30, doi:10.1029/2006JD007272, 2007.

Gaydos, T. M., Stanier, C. O., and Pandis, S. N.: Modeling of in situ ultrafine atmospheric particle formation in the eastern United States, J. Geophys. Res., 110, D07S12, doi:10.1029/2004JD004683, 2005.

Gong, S. L.: A parameterization of sea-salt aerosol source function for sub- and super-micron particles, Global Biogeochem. Cy., 17(4), 1097, doi:10.1029/2003GB002079, 2003.

Guenther, A., Hewitt, C. N., Erickson D., et al: A global model of natural volatile organic compound emissions, J. Geophys. Res., 100, 8873-8892, 1995.

Jung, J, Adams, P. J., and Pandis, S. N.: Simulating the size distribution and chemical composition of ultrafine particles during nucleation events, Atmos. Environ., 40, 2248-2259, 2006.

Kazil, J., Lovejoy, E. R., Barth, M. C., and O'Brien, K.: Aerosol nucleation over oceans and the role of galactic cosmic rays, At- mos. Chem. Phys., 6, 4905-4924, 2006, http://www.atmos-chem-phys.net/6/4905/2006/.

Kerminen, V.-M., and Kulmala, M.: Analytical formulae connecting the 'real' and the apparent nucleation rate and the nuclei number concentration for atmospheric nucleation events, J. Aerosol Sci., 33, 609-622, 2002.

Kettle, A., Andreae, M.: Flux of dimethylsulfide from the oceans: A comparison of updated data sets and flux models, J. Geophys. Res., 105, 26793-26808, 2000.

Korhonen, H., Carslaw, K. S., Spracklen, D. V., Mann, G., W., and Woodhouse, M. T.: Influence of oceanic dimethyl sulfide emissions on cloud condensation nuclei concentrations and seasonality over the remote Southern Hemisphere oceans: A global model study, J. Geophys. Res.-Atmos., 113, D15204, doi:10.1029/2007JD009718, 2008.

Kuang, C., McMurry, P. H., McCormick, A. V., and Eisele, F. L.: Dependence of nucleation rates on sulfuric acid vapor concentration in diverse atmospheric locations, J. Geophys. Res., 113, D10209, doi:10.1029/2007JD009253, 2008.

Kulmala, M., Laaksonen, A., and Pirjola, L.: Parameterizations for sulfuric acid/water nucleation rates, J. Geophys. Res.-Atmos., 103(D7), 8301-8307, 1998.

Kulmala, M., Vehkamäki, H., Petäjä, T., Dal Maso, M., Lauri, A., Kerminen, V.-M., Birmili, W., and McMurry, P. H.: Formation and growth of ultrafine atmospheric particles: a review of observations, J. Aerosol Sci., 35, 143-176, 2004.

Kulmala, M., Lehtinen, K. E. J., and Laaksonen, A.: Cluster activation theory as an explanation of the linear dependence between formation rate of $3 \mathrm{~nm}$ particles and sulphuric acid concentration, Atmos. Chem. Phys., 6, 787-793, 2006, http://www.atmos-chem-phys.net/6/787/2006/.

Kulmala, M. and Kerminen, V.-M.: On the formation and growth of atmospheric nanoparticles, Atmos. Res., 90, 132-150, doi:10.1016/j.atmosres.2008.01.005, 2008.

Laaksonen, A., Kulmala, M., O’Dowd, C. D., Joutsensaari, J., Vaattovaara, P., Mikkonen, S., Lehtinen, K. E. J., Sogacheva, L., Dal Maso, M., Aalto, P., Petäjä, T., Sogachev, A., Yoon, Y. J., Lihavainen, H., Nilsson, D., Facchini, M. C., Cavalli, F., Fuzzi, S., Hoffmann, T., Arnold, F., Hanke, M., Sellegri, K., Umann, B., Junkermann, W., Coe, H., Allan, J. D., Alfarra, M. R., Worsnop, D. R., Riekkola, M. -L., Hyötyläinen, T., and Viisanen, Y.: The role of VOC oxidation products in continental new particle formation, Atmos. Chem. Phys., 8, 2657-2665, 2008, http://www.atmos-chem-phys.net/8/2657/2008/.

Lohmann, U., Stier, P., Hoose, C., Ferrachat, S., Kloster, S., Roeckner, E., and Zhang, J.: Cloud microphysics and aerosol indirect effects in the global climate model ECHAM5-HAM, Atmos. Chem. Phys., 7, 3425-3446, 2007, http://www.atmos-chem-phys.net/7/3425/2007/.

Lovejoy, E. R., Curtius, J., and Froyd, K. D.: Atmospheric ioninduced nucleation of sulfuric acid and water, J. Geophys. Res., 109, D08204, doi:10.1029/2003JD004460, 2004.

Lyubovtseva, Y. S., Sogacheva, L., Dal Maso, M., Bonn, B., Keronen, P., and Kulmala, M.: Seasonal variations of trace gases, meteorological parameters, and formation of aerosols in boreal forest, Bor. Environ. Res., 10, 493-510, 2005.

Makkonen, R., Asmi, A., Korhonen, H., Kokkola, H., Järvenoja, S., Räisänen, P., Lehtinen, K. E. J., Laaksonen, A., Kerminen, V.-M.Järvinen, H., Lohmann, U., Feichter, J., and Kulmala, 
M.: Sensitivity of aerosol concentrations and cloud properties to nucleation and secondary organic distribution in ECHAM5HAM global circulation model, Atmos. Chem. Phys.,9,1747$1766,2009$.

Manktelow, P. T., Carslaw, K. S., Mann, G. W., and Spracklen, D. V.: The impact of dust on sulfate aerosol, $\mathrm{CN}$ and $\mathrm{CCN}$ during an East Asian dust storm, Atmos. Chem. Phys. Discuss., 9, 1477114823, 2009, http://www.atmos-chem-phys-discuss.net/9/14771/2009/.

Martensson, E., Nilsson, E., Leeuw, G., Cohen, L., and Hansson, H.: Laboratory simulations and parameterization of the primary marine aerosol production, J. Geophys. Res.-Atmos., 108(D9), 4297, doi:10.1029/2002JD002263, 2003.

Merikanto, J., Spracklen, D. V., Pringle, K. J., and Carslaw, K. S.: Effects of boundary layer particle formation on cloud droplet number and changes in cloud albedo from 1850 to 2000, Atmos. Chem. Phys. Discuss., 9, 5263-5287, 2009, http://www.atmos-chem-phys-discuss.net/9/5263/2009/.

Nenes, A. and Seinfeld, J. H.: Parameterization of cloud droplet formation in global climate models, J. Geophys. Res.-Atmos., 108(D14), 4415, doi:10.1029/2002JD002911, 2003.

Nightingale, P., Liss, P., and Schlosser, P.: Measurements of air-sea gas transfer during an open ocean algal bloom, Geophys. Res. Lett., 27(14), 2117-2120, 2000.

O'Dowd, C. D. and de Leeuw, G.: Marine Aerosol Production: a review of the current knowledge, Phil. Trans. R. Soc. A., 365, 1753-1774, doi:10.1098/rsta.2007.2043, 2007.

Petters, M. D. and Kreidenweis, S. M.: A single parameter representation of hygroscopic growth and cloud condensation nucleus activity, Atmos. Chem. Phys., 7, 1961-1971, 2007,

http://www.atmos-chem-phys.net/7/1961/2007/.

Pierce, J. R. and Adams, P. J.: Global evaluation of $\mathrm{CCN}$ formation by direct emission of sea salt and growth of ultrafine sea salt, J. Geophys. Res.-Atmos., 111, D06203, doi:10.1029/2005JD006186, 2006.

Pierce, J. R. and Adams, P. J.: Efficiency of cloud condensation nuclei formation from ultrafine particles, Atmos. Chem. Phys., 7, 1367-1379, 2007,

http://www.atmos-chem-phys.net/7/1367/2007/.

Pierce, J. R., Chen, K., and Adams, P. J.: Contribution of primary carbonaceous aerosol to cloud condensation nuclei: processes and uncertainties evaluated with a global aerosol microphysics model, Atmos. Chem. Phys., 7, 5447-5466, 2007,

http://www.atmos-chem-phys.net/7/5447/2007/.

Pierce, J. R. and Adams, P. J.: Uncertainty in global CCN concentrations from uncertain aerosol nucleation and primary emission rates, Atmos. Chem. Phys., 9, 1339-1356, 2009,

http://www.atmos-chem-phys.net/9/1339/2009/.

Raes, F.: Entrainment of free tropospheric aerosols as a regulating mechanism for cloud condensation nuclei in the remote marine boundary layer, J. Geophys. Res., 100, 2893-2903, 1995.

Raes, F., Van Dingenen, R., Vignati, E., Wilson, J., Putaud, J.-P., Seinfeld, J. H., and Adams, P.: Formation and cycling of aerosols in the global troposphere, Atmos. Environ., 34, 4215-4240, 2000.

Riipinen, I., Sihto, S.-L., Kulmala, M., Arnold, F., Dal Maso, M., Birmili, W., Saarnio, K., Teinilä, K., Kerminen, V.-M., Laaksonen, A., and Lehtinen, K. E. J.: Connections between atmospheric sulphuric acid and new particle formation during QUEST III-IV campaigns in Heidelberg and Hyytiälä, Atmos. Chem.
Phys., 7, 1899-1914, 2007,

http://www.atmos-chem-phys.net/7/1899/2007/.

Rodhe, H.: Human impact on the atmospheric sulphur balance, Tellus A-B, 51, 110-122, 1999.

Schroder F. P., Karcher, B., Fiebig, M., and Petzold, A.: Aerosol states in the free troposphere at northern midlatitudes, J. Geophys. Res., 107(D21), 8126, doi:10.1029/2000JD000194, 2002.

Sihto, S.-L., Kulmala, M., Kerminen, V.-M., Dal Maso, M., Petäjä, T., Riipinen, I., Korhonen, H., Arnold, F., Janson, R., Boy, M., Laaksonen, A., and Lehtinen, K. E. J.: Atmospheric sulphuric acid and aerosol formation: implications from atmospheric measurements for nucleation and early growth mechanisms, Atmos. Chem. Phys., 6, 4079-4091, 2006, http://www.atmos-chem-phys.net/6/4079/2006/.

Smith, S. J., Pitcher, H., and Wigley, T. M. L.: Global and regional anthropogenic sulfur dioxide emissions, Global Planet. Change, 29, 99-119, doi:10.1016/S0921-8181(00)00057-6, 2002.

Sogacheva, L., Saukkonen, L., Nilsson, E. D., Dal Maso, M., Schultz, D. M., De Leeuw, G., and Kulmala, M.: New aerosol particle formation in different synoptip situations at Hyytiälä, Southern Finland, Tellus, 60(4), 485-494, 2008.

Spracklen, D. V., Pringle, K. J., Carslaw, K. S., Chipperfield, M. P., and Mann, G. W.: A global off-line model of size-resolved aerosol microphysics: I. Model development and prediction of aerosol properties, Atmos. Chem. Phys., 5, 2227-2252, 2005, http://www.atmos-chem-phys.net/5/2227/2005/.

Spracklen, D. V., Pringle, K. J., Carslaw, K. S., Chipperfield, M. P., and Mann, G. W.: A global off-line model of size-resolved aerosol microphysics: II. Identification of key uncertainties, Atmos. Chem. Phys., 5, 3233-3250, 2005,

http://www.atmos-chem-phys.net/5/3233/2005/.

Spracklen, D. V., Carslaw, K. S., Kulmala, M., Kerminen, V.-M., Mann, G. W., and Sihto, S.-L.: The contribution of boundary layer nucleation events to total particle concentrations on regional and global scales, Atmos. Chem. Phys., 6, 5631-5648, 2006, http://www.atmos-chem-phys.net/6/5631/2006/.

Spracklen, D. V., Carslaw, K. S., Kulmala, M., Kerminen, V.-M., Sihto, S.-L., Riipinen, I., Merikanto, J., Mann, G. W., Chipperfield, M. P., Wiedensohler, A., Birmili, W., and Lihavainen, H.: Contribution of particle formation to global condensation nuclei concentrations, Geophys. Res. Lett., 35, L06808, doi:10.1029/2007GL033038, 2008.

Spracklen, D. V., Pringle, K. J., Carslaw, K. S., Mann, G. W., Manktelow, P., and Heintzenberg, J.: Evaluation of a global aerosol microphysics model against size-resolved particle statistics in the marine atmosphere, Atmos. Chem. Phys., 7, 2073-2090, 2007, http://www.atmos-chem-phys.net/7/2073/2007/.

Spracklen, D. V., Merikanto, J., Carslaw, K. S., et al: Explaining global surface aerosol concentrations in terms of primary emissions and nucleation, in preparation, Atmos. Chem. Phys. Discuss., 2009.

Stier, P., Feichter, J., Kinne, S., Kloster, S., Vignati, E., Wilson, J., Ganzeveld, L., Tegen, I., Werner, M., Balkanski, Y., Schulz, M., Boucher, O., Minikin, A., and Petzold, A.: The aerosolclimate model ECHAM5-HAM, Atmos. Chem. Phys., 5, 11251156, 2005, http://www.atmos-chem-phys.net/5/1125/2005/.

Stier, P., Feichter, J., Kloster, S., Vignati, E., and Wilson, J.: Emission-Induced Nonlinearities in the Global Aerosol System: Results from the ECHAM5-HAM Aerosol-Climate Model, J. 
Climate, 19(16), 3845-3862, 2006.

Twohy, C. H., Clement, C. F., Gandrud, B. W., Weinheimer, A. J., Campos, T. L., Baumgardner, D., Brune, W. H., Faloona, I., Sachse, G. W., Vay, S. A., and Tan, D.: Deep convection as a source of new particles in the midlatitude upper troposphere, J. Geophys. Res., 107, 4560, doi:10.1029/2001JD000323, 2002

Vehkamäki, H., Kulmala, M., Napari, I., Lehtinen, K. E. J., Timmreck, C., Noppel, M., and Laaksonen, A.: An improved parameterization for sulphuric acid-water nucleation rates for tropospheric and stratospheric conditions, J. Geophys. Res., 107(D22), 4622, doi:10.1029/2002JD002184, 2002.

Vignati, E., Wilson, J., and Stier P.: M7: An efficient size-resolved aerosol microphysics module for large-scale aerosol transport models, J. Geophys. Res., 109, D22202, doi:10.1029/2003JD004485, 2004.

Wang, M. and Penner, J. E.: Aerosol indirect forcing in a global model with particle nucleation, Atmos. Chem. Phys., 9, 239-260, 2009, http://www.atmos-chem-phys.net/9/239/2009/.

Wang, M., Penner, J. E., and Liu, X.: The coupled IMPACT aerosol and NCAR CAM3 climate model: evaluation of predicted aerosol number and size distribution, J. Geophys. Res., D06302, doi:10.1029/2008JD010459, 2009.

Weber, R. J., McMurry, P. H., Eisele, F. L., and Tanner, D. J.: Measurements of expected nucleation precursor species and 3500nm diameter particles at Mauna Loa observatory, Hawaii, J. Atmos. Sci., 52, 2242-2257, 1995.
Weber, R. J., McMurry, P. H., Eisele, F. L., Tanner, D. J., and Jefferson, A.: Measurements of new particle formation and ultrafine particle growth rates at a clean continental site, J. Geophys. Res., 102, 4375-4385, 1997.

Williams, J., de Reus, M., Krejci, R., Fischer, H., and Strm, J.: Application of the variability-size relationship to atmospheric aerosol studies: estimating aerosol lifetimes and ages, Atmos. Chem. Phys., 2, 133-145, 2002, http://www.atmos-chem-phys.net/2/133/2002/.

Young, L. H., Benson, D. R., Kameel, F. R., Pierce, J. R., Junninen, H., Kulmala, M., and Lee, S.-H.: Laboratory studies of $\mathrm{H}_{2} \mathrm{SO}_{4} / \mathrm{H}_{2} \mathrm{O}$ binary homogeneous nucleation from the $\mathrm{SO}_{2}+$ $\mathrm{OH}$ reaction: evaluation of the experimental setup and preliminary results, Atmos. Chem. Phys., 8, 4997-5016, 2008, http://www.atmos-chem-phys.net/8/4997/2008/.

Yu, F., Wang, Z., Luo, G., and Turco, R.: Ion-mediated nucleation as an important global source of tropospheric aerosols, Atmos. Chem. Phys., 8, 2537-2554, 2008, http://www.atmos-chem-phys.net/8/2537/2008/.

Zhang, R., Khalizov, A. F., Pagels, J., Zhang, D., Xue, H., and McMurry, P. H.: Variability in morphology, hygroscopicity, and optical properties of soot aerosols during atmospheric processing, PNAS, 105(30), 10291-10296, doi:10.1073/pnas.0804860105, 2008. 